BINYAM MEKONNEN ADERA, Addis Ababa University (Ethiopia)

e-mail: binyam.mekonnen@aau.edu.et, ORCID https://orcid.org/0000-0002-9193-8904

\title{
SOCIAL MEDIA, PUBLIC SPHERE AND THE POLITICAL TRAGEDIES OF CONTEMPORARY ETHIOPIA
}

\begin{abstract}
Ethiopia since 1991 G.C has been adopting democracy and federalism as constitutional frameworks of the state. The core objective to maintain the two political cultures is the presence of multiple cultural identities within the state and the actual need for an intersubjective discussion on the public sphere. And one of the major areas of public sphere is the social media. As per the Constitution of the Federal Democratic Republic of Ethiopia citizens of Ethiopia have the democratic rights of Thoughts, Opinion and Expression (Art. 29), so in social media it is natural to expect that individuals talk on the different affairs of the state 'freely'.

Basically the social media is serving as an instrument in maintaining discursive talk among individuals. However, it has been also producing considerable social turmoil across the world. The same is what is encountering in Ethiopia today; on the one hand, social media as a communication platform allows people to communicate effectively with sharing alternative views, attitudes and forming democratic consensus on the social anomalies and responses, and on the other hand, the media is the sphere of communicative maladjustment where misunderstanding, extremism and miscommunication is producing. In the present Ethiopian context the basic source of communication and miscommunication in the social media is the 'pluriversal identities' of the cultural horizon. Taking this as a crucial object, this article will discuss the connection between democracy, federalism and social media in the current Ethiopia. On the top of this, the study aims at exploring the following issues: the social media sphere in Ethiopia, the modern and postmodern challenges of social media in Ethiopia and alternatives for the social media reconstruction.
\end{abstract}

Key words: social media, federalism, democracy, communicative rationality, public sphere.

\section{Introduction}

It is a generally thought that we are in the age of electro-technological globalization; information flows from one corner to the other within a microsecond about the diverse issues of life. The telecom, electronic and other communication media are narrowing the gap of the world into a village devaluing the older governing principle of space and time. As a part of modernization, instruments of modernity's project technological and scientific achievements contributed significantly in shaping the human interaction and communication. To look at this on the particular subject of democracy, media contributed a lot in transforming the public sphere. The public sphere is the area that individuals intersubjectively exercise discursive talk as the way that they can develop their essential freedom of expression. On this line, social media are serving as a major platform in redefining the democratic culture of relations where citizens construct their political and personal views underling that the right to expression rooted in a linguistic communication. That is why some scholars viewed social media as an extension of democracy. (Engelstad, Fredrik, et al., 2017: 16)

One would say the political culture of democracy is in progress when the relations among citizens and citizengovernment are maintained with an intersubjective deliberation. The German profound writer of theory of communication, Jürgen Habermas articulated that the modern political interconnections between freedom, democracy and some other values of modernity are truly constructed by scheme of linguistic deliberation;

...the Enlightenment values of freedom, democracy, individuality, autonomy, criticism, and rationality; with analysing their interconnections; with understanding how they have been threatened by development within modernity; and with demonstrating how these values can be anchored in actual social institutions through advancing existing forms of "communicative action". The rationality that informs such action is based on raising and evaluating validity claims within an intersubjective context oriented toward achieving rational consensus over social values and policies. (Best, 1995: 148-149)

As far as Habermas is concerned, act of deliberation is important in banishing the conventional and barbaric metaphysical foundation of strategic communication. This is an attempt to situate communication in the public sphere where individuals express their natural right in questioning as well as dismantling the 'pre-existing structures', and replacing by communicative rationality which seeks for a critical-pragmatic determination (Hoy and McCarthy, 1994: 75-77). With the role of social media most people believe that an excessive right is secured to express whatever individuals feel. This is basically associated with the web technological advancement within which hierarchical controlling tools are destroyed. Unlike 
conventional/mainstream media, social media require the autonomy of users to handle every case by their own. This would help us to see social media as they operate through the subjective power ownership, control and selfgovernmental responsibility. This has a great political implication in the sense that individuals are power holders, makers and managers.

This excessive seek has both positive and negative consequences. The positive asset of social media is that individuals become free to exercise the democratic right of expression. And this is a golden value to understand politics as the public sphere of individuals' participation, self-determination, self-realization, rational consensus production, etc. But on the other hand, social media is creating a number of crises in personal and social affairs. Among other we can mention the communicative failure, animosities, and conflicts. That is the reason for many scholars today arguing that social media is an equivocal instrument of communication. Scholars like Adams Oluwadamilola Kemi (2016), P.S. Jeesmitha (2019) and Fredrik Engelstad, et al (2017) reflected that social media has been operating in both bad good faces. This is to indicate that the medium has two faces.

The social media enormously increase the opportunity for ordinary citizens to express their personal and political views. At the same time, this improvement in the freedom of expression is counteracted by the increased opportunity to pester other people....with the result that many prospective participants in political debates withdraw from the public space to escape harassment. (Engelstad, Fredrik, et al., 2017: 16)

The impact of social media in the present Ethiopia is not far from the ambiguous image that I presented just before. As most of us expressing Ethiopia as a nation is building its political structure on a democratic path. Of course democracy contained diverse values which can be measured by its own theoretical and practical characteristics. In addition to this, democracy cannot be a short term program at the political level given that its values' transformation resulted from individuals' changes and intersubjective interconnections. So democracy requires a critical-pragmatic investigation into its theoretical and historical developments.

So this paper examines the democratic essence of the present Ethiopia in line with the political structure of federalism and the tensions of social media as an expressive tool of freedom, most importantly, freedom of expression. So with this I will examine the existential constitution of Ethiopia in its specific article 29 from the on-going debates of individual and group rights priority, the actual miscommunications and prejudices of social media. The methodology used in developing this article is purely qualitative. Desk research was conducted to understand and philosophically examine the impact of social media across the world with special emphasis on the existing political situation of Ethiopia.

\section{Purpose of the Article}

The purpose of this article is to explore the impact of social media on the current political situation of Ethiopia. Given the fact that Ethiopia is one of the most ethnically diverse nations in Africa the political system of federalism has to be critically examined from the perspective of an intersubjective communication process. The way in which people are using social media in contemporary Ethiopia requires a systematic inquire to reset the real and effective political objectives of genuine discursive communication.

\section{Research Methodology}

This study seeks to understand how social media is used in the promotion of democratic political culture in the contemporary Ethiopia. It approaches the conceptual relation between social media and an intersubjective communication from a philosophical perspective. As a methodology it relies more on secondary data sources including books, journal articles and media outlets regarding the functional and dysfunctional contents of social media. lues

1) Interrogating Social Media and Democratic Va-

A) The Social Media and the Public Space of Communication

The dominant description of social media says that new forms of interconnections are designed and public discourses emerged in a deliberative dialogue. This is the account to consider social media as a novel form of public sphere. Public sphere is defined by Habermas as an area where public thoughts can be produced. In his 1991 published book, the Structural Transformation of the Public Sphere: An Inquiry into a Category of Bourgeoisie Society Habermas noted that public places are open to everybody regardless of any cultural identity. Based on such view of public sphere, individuals express their political interest that they develop through a rational reflection, and so that everything is ready for discussion and consensus formation. So the public sphere recognizes the equality of all participants as well as the free expression of opinions.

The exchanging of ideas and interaction between the individuals has reached the higher level these days thanks to social media platforms like Facebook, Twitter, YouTube and others. With these media users can communicate freely with each other and consequently can come together for a certain goal. Communicating online means to publish online which on the other hand refer to connecting online with other people. The published content in the social media is reachable for anyone throughout the world eliminating in this way the physical and infrastructure obstacles whereby the freedom of speech is the freedom of press and as a result it is also the freedom of gathering together. (Çela, 2015: 196)

In this sense one can infer that social media revolutionizes the political culture of democracy by combining the freedoms of expression, press and assembly. This typical triple articulation of freedom makes social media a decisive instrument in reconceptualising not only the original picture of public spheres, but also the time-space orientation. The older image of public sphere as public houses with social media was transformed into technological zones, and the older images of temporality and spatiality with the same media technology was transformed into new forms time and space conceptions. With the emergence of social networking, space and time enlarge into 'electronic space' and 'internet time' (Tsatsou, 2009: 1922). With such transformations the political culture of democracy is changing, too. It is here we can find the mod- 
ern character of social media as they promote deliberative rationality and intersubjective communication in the public sphere. This argument underscores the complementarity between social media and the public sphere.

However, there is a counter argument which says social media is more definable with a postmodern attribute. As oppose to the modern characteristics of social media, a postmodern outlook generally asserts that the media is promoting personal and conflict-based interests of individuals who take into account communicative degradation, disagreements, violence and crimes. On this line social media are used to maximize personal power exercise as oppose to the common interest of rational deliberation. Contrary to the public sphere idea, the postmodern views of social media accept the fact that individuals have the right to expresses their personal as well as cultural feelings in a purely sentimental fashion, and thus, nobody is authoritative to establish a universal order on how to use medium of communication. Especially the worldwide popular social technologies such as Facebook, Twitter and the like could be used as a political means of individuals' exclusive sentimental expressions which cannot be objectified to have universal rules and regulations. In this respect Jodi Dean notes that internet which includes social media are more using as a refutation of the doctrine of public sphere emphasizing that rational deliberations are utopic to the social networking sites. Dean says that today social media sites are serving as a means for the promotion of egoism, antagonism and exclusivism. The fundamental point of Dean is that social media lacks public sphere essence which tends destroys the organic faceto-face interactions. (Dean, 2003: 98)

Politically speaking, when the postmodernists associate the social media with the private and social spaces, they are consciously questioning and rejecting the public sphere norms of liberal democracy and its cultural hegemony. The goal of this understanding is to critically examine the role of social media in relation to the economic and political ideologies of the global system and the contextual manipulations of the technology itself. Is really social media a public sphere? How far are we sure there is a demarcation between the public sphere and other spheres or the lifeworld? These two questions somewhat help us to assess the social media use in the current Ethiopian politics.

\section{B) The Social Media and Contemporary Ethiopian}

\section{Political Issues}

It is a very recent phenomenon that we can talk about the nexus between social media and the politics of Ethiopia. This is because social media is providing its crucial impact on Ethiopian politics since the past few years. Even though the period is too short, the impact that social media brought to the country's political worldview is incredible. The dominant historical discourses outlined that Ethiopia began a democratic political culture when the Derg was displaced and Ehadig/EPRDF came to power. EPRDF introduced the federal and democratic principles as the core value in reconstructing the political history and philosophy of Ethiopia. Ethiopia has been experiencing a new form of federalism, i.e. ethnic federalism since 1991. Fasil Nahum (1997) wrote that even the EPRDF government re-established democracy as it is rooted in the promotion and protection of ethnic identity and equality.

After the 1994 Ethiopian Constitution came to the political sphere, the EPRDF government has been idealizing its regime as a guardian of democracy. This thinking resulted primarily from the legal and political protection of group rights. Among other, by this constitution it is affirmed that the owner of sovereign power is the Nations, Nationalities and Peoples of Ethiopia (Article 8 (1)). In addition, the Constitution declared the right to selfdetermination. This specific right goes to extent the right to secession of each nation, nationality and peoples of Ethiopia (Article 39). On this specific article there is a serious challenge which contradicts the very logical articulation of federalism itself.

On the top of this, the 1994 Constitution clearly stated the rights of thoughts, opinion and expression as a major democratic value. On this ground every Ethiopian citizen has autonomous space for expression. To link this with the social media use, then Ethiopians are free to express the idea that they have on political, economic, cultural and other affairs. The question what it appears is that what is the account of social media in Ethiopia today? Is the medium a truly public sphere where people are socially connected?

While acknowledging the argument of modernists like Habermas it is possible to argue that the social media in every society including Ethiopia serve as a public space to exercise liberal democracy and freedoms. The freedoms are associated with speech, assembly, press, thought, opinion and expression. In his Structural Transformation of the Public Sphere Habermas takes public sphere as an area of communication, which is a communication with divergent views? The divergent views in Habermasian sense refer different ideas and thoughts which are ready for a discursive dialogue (Habermas, 1991: 31). How about us? For the past few years the Ethiopians are using social media as means of expression. This is not a deniable fact. But the way in which the rights of thoughts, opinion and expression which have been presented on the social media more reflect sentimental views. Most fake news, hate speeches, irresponsible sensationalism, violence announcements and other related feelings and acts disseminated as a form of information. In this regard, individuals used their right to expression not basically for deliberative communication, but instead to attack and violate others' rights through the social media platform.

\section{2) Modern and Postmodern Challenges of Social Media in Ethiopia}

A) Freedom of Expression and Social Media: Modern and Postmodern Debates

Freedom of expression has been mainstreamed as an essential component of democracy in the modern society. Freedom of expression allows the free flow of information, interpretations and reinterpretations, institutions and institutional structures and regulations. That is the major reason for Habermas' articulation of freedom within an act of communicative rationality in the public sphere;

The set of basic rights concerned the sphere of public engaged in rational critical debate (freedom of opinion and speech, freedom of press, freedom of assembly and association etc.) and the political 
function of private people in this public sphere (right of petition, equality of vote etc.). (Habermas, 1991: 83)

The modern conception of freedom of expression provides credible procedures on the way that individuals make public opinion. The assumption is that for a long period of time people lost their democratic rights in the pre-modern political structure. The pre-modern political structure refers to the system in which individuals are not yet enlightened. In this political structure individuals are no longer to be sovereign.

Based on the modern picture of politics, social media can be taken as an instrument of public opinion formation employing three foundational attributes of public sphere dimensions. The three dimensions are 1) Structural, 2) Symbolic and 3) Interactional. The three dimensions imply that social media are social engineering tools where information freely flows, signs and symbols are codified in a two-way communication (Brenne, 2016: 271). This seems a basic line to justify that social media have rational regulatory mechanisms on the free access and free communication of information. As the public sphere individuals make an intersubjective course of communication considering that individuals are not only privileged for their rights, but also respecting others as an obligation, too. So in this regard one may claim that social media give both freedom and responsibility as centre of deliberative communication.

But this has a strong criticism on the enlightenment potential of individuals. For instance, we can present here the negative implications of instrumental and technological rationalities. The instrumental rationality, as it is well discussed by Max Horkheimer and Theodor Adorno signifies that rationality of modern era seems to lead to destruction, violence and the dictatorship of a mystic power. Both Horkheimer and Adorno say that the modern scientific and technological tools are designed to manipulate the natural interaction of human beings among themselves and other agents. Thus, they insist that the fear and the myth of the pre-modern period were still preserved although they were transported into the totalized project of modernity in tragic form. (Horkheimer and Adorno, 1982: 3-5)

Herbert Marcuse like the above mentioned scholars challenged the modernity's speculation of rationality. His basic argument says that technological rationality is nothing more other than a political weapon of destruction and exploitation. "Technological rationality reveals its political character as it becomes the great vehicle of better domination, creating a truly totalitarian universe in which society and nature, mind and body are kept in a state of permanent mobilization for the defence of this universe" (Marcuse, 2007: 20). By this technological rationality it refers that the everyday horizon of life is controlled more in a political structure. That would be an account to take this rationality as matter of colonizing instead of liberating life itself. When we particularly situate this technological rationality in the social media context, then we can find a challenge that technological structures have been robbing the liberty of individuals. The simplest factor for the deprivation of the freedom of individuals is that the social media have a political platform to create a single-form of society. By this logic therefore social media are not truly public spheres where individual talk freely and share in- formation as they go for rational consensus. Rather, social media designed for political purpose of creating society at global level in its one-dimensional form.

Moreover, most violence in the modern and postmodern worlds occurs due to the wrong use of media in the political sphere. People only give attention to the external enforcement mechanism of media which has a multiple interpretations of morality. In both modern and postmodern dominant discourses moral values were trans-valued given that they lack systemic arrangement and universal order. Virginia Held insisted that moral judgments trans-valued by the media industry, and thus political grievances came to an essential description of contemporary world. Held (2008) said that media have to serve as a moral space to assure rationalities and actions on their intrinsic values.

...the media need to engage in meaningful discussion of what positions are politically better or worse and make strong cases for justifiable positions. This means they would have to consider questions such as whether it may be justifiable to break laws against political violence and why it usually is not. They would have to raise questions of priority of morality over law and deal with them in substantial and adequate ways. The law itself cannot recognize a priority for morality, but where freedom of expression is protected, the media are entirely able to engage in moral discourse over the justifiability of civil disobedience, illegal dissent, political violence, and the like. (Held, 2008: 116117)

Social networking sites are highly accused with the ethical fallibility since the sites have no intension of control over the users. Thus, users are free to crate whatever accounts including the fake ones. Besides, there is no control over the users in what they can write, post, like and comment. Social media are designed to express people's thought with no external enforcement. This makes the social media sensitive to talk on the line of control. In this one may expect that the users are the one who are responsible to employ primarily an ethical rule in their expression of freedom. This is to argue that social media users are not only freely expressing whatsoever they think, but also they should respect the rights of others.

Nevertheless, the users' management on the media has a number of negative consequences in the world in general, and Ethiopia in particular. The social media users are more conscious about the freedom that they have, not the responsibility they should show to others. And this creates an ethical challenge on the communication process. As we know communication is about interaction and social duty of searching truth. Despite this, in social media most people claim that they possess truth individually at personal level or in small and large social groups. By this social media violate the construction of the possible highest form social truth and reality remaining on narrow identity presentation. Today in Ethiopia significant number of people is using social media to glorify the personal and ethnic identities which ignores the possibility of phenomenological reflection. This phenomenological reflection is basic to know the individual as responsible figure in presenting the self to the world within 
which s/he lives. S/he is the responsible agent to face others in broadening the horizon of perception.

Phenomenological reflection is capable not only of taking us into the deeper dimension of subjectivity, there where such responsibility and obligation will reveal themselves; it is also capable of strengthening our mindfulness, sharping our perception of the specific, concert situations in which we find ourselves, sharpening our perception of what response each situation calls for. (Kleinberg-Levin, 2008: 22)

The existential crises of social media largely resulted from the irrational and egoistic image of self-perception. This arises from the thinking of the self always places itself in a closed system that is not only separated from the identity of the 'Other' but also from itself. To put oneself in a closed system means to remain in absolute isolation and a non-flux identity construction. Gabrielle Hiltmann noted that the identity of individuals is always in change, and hence, there has to be a potential openness of the self to the 'Other' and to itself to constitute an ethical wholeness. The disclosure of the self to the 'Other' and to itself is mediated through relation and communicative ethics. (Hiltmann, 2007: 11)

\section{B) The Social Media Dynamics and Democracy in Contemporary Ethiopia}

In multicultural societies like Ethiopia it is obvious to find hostile interests among individuals and groups. The federal structure of the nation accepts the fact that there exists diversity in culture, religion, language, etc. But in communication process, very particularly on social media, what we are experiencing is that individuals attack each other in fostering trans-valuations of values, political turmoil, psychological and cultural insults. The crucial point here is that social media are not actually public spheres of communication. Rather they are private and cultural domains where by individuals exercising their excessive power to exploit others. Irrational political violence, sexual violence and ethical destructions are made by social media sites. We are encountering serious violence in contemporary Ethiopia via social media in the name of freedom of expression.

The ethnic federalism philosophy adopted by the EPRDF has its own crucial impact on how people should communicate with each other considering the ethnic and cultural diversities, and the fact that there is a dialectical correlation. With a dialectical process, ethnic and cultural hybridity as well as conflicts are emerging. The political strategy of ethnic federalism has attributed a lot to publicly discuss about ethnic identity as a sensitive concern in contemporary Ethiopia. Some thinkers articulated that the ethnic-based federalism of Ethiopia is important to assure the idea of self-governance in its recognition of cultural and linguistic diversities of nation, nationalities and people. Despite this, others argued, ethnic federalism of Ethiopia is the long-lasting political project of Tigray People Liberation Front (TPLF). This argument says that TPLF developed into EPRDF affirming not the decentralization of power among plural identities, but instead the legitimization of ethnic hegemony one over the other (Muhabie, 2015: 101). For almost three decades, ethnic federalism of Ethiopia has been the core question at the political level. Consequently, in the social media we have been encountering arguments, counterarguments, criticisms, accusations and violence in relation to this.

Prior to the reign of Prime Minister Abiy Ahmed the perception of social media is more ideological. The EPRDF government led by the former Prime Minister $\mathrm{H} /$ Mariam Desalegn most of the time blamed social media users, especially the so-called protestors including opposition party leaders and representatives, political activists and journalists. As the Washington Post writer Paul Scheme wrote on October 14, 2016, H/Mariam was so aggressive in accusing social media users in and outside Ethiopia that he thought the political unrest of his state explicitly caused by the network sites. This is the key factor to block Facebook, Viber and Twitter by that time and after.

On the contrary, the opposition party leaders, most bloggers and activists blamed the EPRDF for its authoritative control of the mainstream media. And they insist that the social media is like their field to communicate with supporters and the rest people that they can challenge the wrong deeds of the government. On this regard, Jawar Mohammed's political activism could be taken as one decisive input how social media contributed in transforming the political criticism and recent revolutions in the country, Ethiopia.

... Jawar was one of many diaspora journalists who took advantage of social media platforms like Twitter and Facebook to bypass strict government censorship. Through these mediums, he helped orchestrate demonstration and broadcast undeniable proof the government's abuses to millions of followers. (Al Jazeera, 2018, August 12)

According to Muluye the protestors are more claiming that the social media is an alternative political space of communication and revolution (2017: 295). This gives a sort of demarcation between the EPRDF and the other group as they use the mainstream and social media as their essential public sphere, respectively.

Once PM Abiy Ahmed came to power there is a paradigm shift on the way both the government and the contesting groups looked at the social media. On April 2, 2018 he gave the ground laying speech as a Prime Minister of Ethiopia stressing that Ethiopians are in "a new era for ethnic unity, democracy and freedom of speech" ( $A l$ Jazeera, 2018, August 12). This is a remarkable decision that Abiy made to reform the political orientation of democracy and federalism in Ethiopia.

Abiy provided his remark on the power of social media showing that there are two sides in which we should be conscious. He said, social media is good if we take it as a means for rational communication and addressing the predicaments of our society. The various historical, social, political and other aspects of ills are waiting for deliberation on this beneficial understanding of social media. On the other hand, the prime minister believed that social media have a negative impact when people use for the purpose of abuse, violence and political glorification of one group over the other(s) (Oromia Tube, 2018, April 4). Situating this in the present Ethiopia, unless people utilize all media in balancing freedom of speech with the duty of respecting others' right, undoubtedly it is impossible to exist as one people and one nation who have certain common goods. 
3) Alternatives for Social Media Reconstruction

How to use social media is a critical concern understanding the nature of freedom of expression and communication. If we think expression of idea and communication go hand to hand we should accept that democratic values of difference, tolerance and respectfulness are central. Bearing this in mind, social media enable us to discuss issues freely, rationally and responsibly. With the development of the modern world, the political relation is in progress. Advancement in technology takes the world into a new form communication. By this logic social media is understood as the transformation of old democratic principles. It is basic then to know the unique appearance of social media in the political system as citizens entertain with art of discursive talk, equal access of information, democratic participation and freedom speech. The way in which we perceive social media starts with fact of the openness a new chapter in the political realization of argumentations and communications.

The reconstruction of social media usage should also take into account sociological structures of society and their rational political platforms. Social media is in fact a global phenomenon. But it has a technological origin from a liberal sociological structure. On this line it is plausible to associate social media with the bourgeoisie public sphere. What seems this public sphere?

The bourgeois public sphere may be conceived above all as the sphere of private people come together as a public; they soon claimed the public sphere regulated from above against the public authorities themselves, to engage them in a debate over the general rules governing relations in the basically privatized but publicly relevant sphere of commodity exchange and social labour. The medium of this political confrontation was peculiar and without historical precedent: people's public use of their reason. (Habermas, 1991: 27)

The base for bourgeoisie public sphere is the liberal ideology of freedom where individuals are autonomous. And culturally this philosophical outlook is highly conceivable in the Western society. Many scholars of the West presented the hegemony of their culture to be a universal value for its emancipative potential. This entails that the cultural philosophy of individualism is structurally transcended to the level that it invades other horizons. It is here one can find the modernization glory of scientific and technological advancements as a political means of exploitation. But this is not simply the rejection of social media. Rather, it is a quest on how can we appropriate in contextual sense. One thing we should underscore here is that the autonomous picture of individuality of the West might not be applicable to other cultural zones for various reasons. It is necessary to understand the incommensurability of autonomy in the West and the rest of the world. So whenever we think about the exportation of tangible and non-tangible cultural values the first thing that has to be questioned is its material significance. By material significance here I used as something contextually important to address the crises around. I think this helps us to see how there is a cultural lag in the nonWestern societies on how to use social media. Social media is more useful for those people who cannot engage in a face-to-face communication. Is that the case for most of the people around us?
Beyond the cultural lag, we should also work on the ethical use of technology, including social media. Ethics is relevant to maintain constructive communication among individuals. One of the reconstructions of social media usage goes through the ethical interactions of individuals while they express ideas, criticisms, supports, etc. Especially those who believe social media is a public sphere they should recognize that media platform are both endowed with privileges and obligations, which are the two sides of a same coin. Ethical assessment has to be taken also on the mainstream/conventional media to assure that there is professionalism in the dissemination of information. The lack and bias of this professionalism on the side of conventional media of Ethiopia caused various damages to exercise the democratic right of accessing trustworthy information and expressing views freely. African $R e-$ port on September 2009 stated the professionalism anomalies of mainstream media in Ethiopia as follows;

The limited professionalism and outreach of the mass media compounds the narrowness of public space. Although there are about 200 newspapers and magazines, few are independent of trustworthy news outlets. Low standards and partisan agendas taint the credibility of the private press. Government-and party-affiliated media are subservient. (2009: 21)

Both the mainstream and social media require ethical adjustments on the level of their authors primarily. It is clear that the mainstream media is not as such difficult to maintain, quality assurance mechanisms for it has its own professionalism. But in social media users are the one who are responsible in the dissemination of real information. Democratically we can argue then, it is fundamental to actively work on the civic virtue of selfgovernance.

Rational communication would be void without selfgovernance. Self-governance is about self-discipline, open-mindedness, generosity and respect for the worth and dignity of others both individually and in groups. Once people seek rational communication they should start with recognition and respect of others. In short, in a democratic communication of media what people need to have is civility in speech. I think if we maintain the right to expression within the notion of self-governance, then we are on the position not only of accepting, but also of appreciating cultural pluralisms and their possible interactions. Put this differently, media including social networking technologies can foster intercultural conversation. Enlightened self-interest can also be reflected to form social truth. For instance, Habermas identified self-governance principle as a tool for political autonomy of religious citizens (Habermas, 2017: 124). This is a liberal outlook which transcends conventional identities into postconventional sphere where democratic conversation is possible. So users of social media should think about not the superiority or inferiority of identity groups in ethnicity, language, spirituality and etc., rather it is rational to accept the civic autonomy of plurality as there is a symmetric relationship.

\section{Conclusion}

The power of social media is more than what we can think about communication in the conventional sense. Social media transcends the mere conception of commu- 
nication. Perhaps, people exchange information through this media. However, from a border point of view, social media is a political instrument whereby freedom is questioned, contest is presented and power is produced. Depending on the impact that social media is making we can reach a conclusion that social media constituted its own new political empire in the world. As a major timely concern it is not that much impressing to take social media as a political phenomenon.

Modernists insist that social media is one of the political spaces where individuals exercise the right of expression. This argument means that social media is a universal technological instrument which is politically relevant to assure liberty, equality and discursive way of making consensus. The nature of this stand point extends the role of social media as a public sphere in maintaining the civic virtues of open-mindedness, respectfulness and tolerance. By this argumentation the pluralist account of any society is in an interpersonal communication within which social truth and intercultural relation are evolving.

On the contrary, postmodernism stressed on the situational interpretation of technology and other means of communication. This has more realistic and pessimistic outlook on social media, and notes that differences and conflict of interests are lively to express individuals and society. Accordingly, social media ignores the ideological assertions of bourgeoisie public sphere for any communication medium is used to maximize one's interest over the other. So the actual aim of social media is not to establish a universal and intersubjective space of communication. Instead, it stands for the realization and promotion of relativism. As a political message postmodernism took social media as a device to present the voice of difference in an uncompromised fashion.

As Ethiopia is following ethnic federalism to be the constitutional base for its democratic apparatus, it is crucial to know how the social media is functioning. Because of the global expansion of instrumental and technological rationality, most people use social media not as a public square to engage on the deliberation and emancipation, but rather to manipulate others and fall into miscommunication. Abuses, hate speeches, ethnic biases and other related facts are creating an absurd world for the majority of people in Ethiopia today due to social media. It seems necessary for all people to examine the rational and ethical way on how they should use social media, and promote virtues of professionalism and civil plurality on the public spheres as a whole. Whenever we use medium of communication there should be a political understanding on the mutual coexistence which is very crucial for nations like Ethiopia in fostering the democratic communication of diverse personal as well as cultural identities.

\section{REFERENCES}

Al Jazeera. (2018, August 12). Social media shaping calls for Ethiopia political change_ The Listening Post [mp4].

Best, Steven. (1995). The Politics of Historical Vision: Marx, Foucault, Habermas. New York and London: the Guilford Press.

Brenne, Sarah. (2016). Political Discussion on Social Media and the Public Sphere. Sociology and Anthropology, 4(4): 270275. http://www.hrpub.org
Çela, Erlis. (2015). Social Media as a New Form of Public Sphere. European Journal of Social Sciences Education and Research, 4(1):195-200.

Dean, Jodi. (2003). Why the Net is not a Public Sphere. Constellations 10(1): 95-112.

Engelstad, Fredrik, Larsen, Håkon, Rogstad, Jon and SteenJohnsen, Kari. (2017). Introduction: The Public Sphere in Change. Institutional Perspectives on Neo-corporatist Society. In Engelstad, Fredrik, Larsen, Håkon, Rogstad, Jon and Steen-Johnsen, Kari (Eds.). Institutional Change in the Public Sphere: Views on the Nordic Model: 1-21. Warsaw, Poland: De Gruyter Open. http://doi.org/10.1515/9783110546330-002

Ethiopia: Ethnic Federalism and Its Discontents. (2009, September 4). African Report $\mathrm{N}^{\circ} 153$.

Fasil Nahum. (1997). Constitution for a Nation of Nations: The Ethiopian Prospect. New Jersey and Asmara: The Red Sea Press.

FDRE. (1995). The Constitution of Federal Democratic of Ethiopia.

Habermas, Jürgen. (1991). The Structural Transformation of the Public Sphere: An Inquiry into a Category of Bourgeois Society. Burger, Thomas (Trans.). Cambridge and Massachusetts: The MIT Press.

(2017). Postmetaphysical Thinking II. Cronin, Ciaran (Trans.). Cambridge: Polity press.

Hiltmann, Gabrielle. (2007). Introduction: Accounting for the Other: Towards an Ethics of Thinking. In Fielding, Helen, Hiltmann, Gabrielle, Olkowski, Dorothea and Reichold, Anne (Eds.). The Other: Feminist Reflections in Held, Virginia. (2008). How Terrorism is Wrong: Morality and Political Violence. New York: Oxford University Press.

Horkhiemer, Max and Adrno, W. Theodor. (1982). Dialectic of Enlightenment. John, Cumming (Trans.). New York: Continuum Publishing.

Ethics. London: Palgrave Macmillan.

Hoy, C. David and McCarthy, Thomas. (1994). Critical Theory. Cambridge: Blackwell Publishers.

Jeesmitha, P.S. (2019). The Impact of Social Media. International Journal of Scientific Research and Engineering Development-- Volume 2 Issue 1.

Kemi, Adams Oluwadamilola. (2016). Impact of Social Network on Society: A Case Study of Abuja. American Scientific Research Journal for Engineering, Technology and Sciences.

Kleinberg-Levin, David Michael. (2008). Before the Voice of Reason: Echoes of Responsibility in Merleau-Ponty's Ecology and Levinas's Ethics. New York: State University of New York Press.

Marcuse, Herbert. (2007). One-Dimensional Man. London and New York: Routledge Classics.

Muhabie Mekonnen Mengistu. (2015). Ethnic Federalism: A Means for Managing or a Triggering Factor for Ethnic Conflicts in Ethiopia. Social Sciences, 4(4): 94-105. http://www.sciencepublishinggroup.com/j/ss

Muluye, T. Ketemaw. (2017). The Status of Political Parties' in Using Social Media for Campaigns During the 2015 General Election of Ethiopia. African Journal of Political Science and International Relations, 11(10): 248-300. http://www.academicjournals. org/AJPSIR

(2018, April 12). PM Abiy Ahmed Speech about Social Media.

Schemm, Paul. (2016, October 14). In the Ethiopia's War against Social Media, the Truth Is the Main Casualty. The Washington Post.

Tsatsou, Panayiota. (2009). Reconceptualising 'Time' and 'Space' in the Era of Electronic Media and Communications. Journal of Media and Communication Vol. 1 (July 2009): 11-32. 
Біньям Меконнен Адера,

Аддис-Абебський університет (Eфіопія)

e-mail: binyam.mekonnen@aau.edu.et, ORCID https://orcid.org/0000-0002-9193-8904

\section{СОЦІАЛЬНІ МЕДІА, ПУБЛІЧНА СФЕРА ТА ПОЛІТИЧНІ ТРАГЕДІЇ СУЧАСНОЇ ЕФІОПІЇ}

31991 р. в Ефіопії демократія та федералізм сприймаються як конституційні основи держави. Основною метою підтримки двох політичних культур є наявність у державі численних культурних ідентичностей та фактична потреба в міжсуб'єктивному обговоренні суспільної сфери. І однією 3 основних сфер публічної соери є соціальні медіа. Відповідно до Конституції Федеративної Демократичної Республіки Ефіопія, громадяни Ефіопії мають демократичні права на думки, позиції та висловлювання (ст. 29), тому в соціальних мережах цілком природно очікувати, що окремі люди говорять про різні справи держави вільно.

По суті, соціальні медіа служать інструментом підтримки дискурсивних розмов між людьми. Однак це також спричинило значні суспільні потрясіння у всьому світі. Те ж саме відбувається сьогодні в Ефіопії. 3 одного боку, соціальні медіа як комунікаційна платформа дозволяють людям ефективно спілкуватися, обмінюючись альтернативними поглядами, установками та формуючи демократичний консенсус щодо соціальних аномалій та відповідей, а з іншого боку, медіа - це сфера комунікативної дезадаптованості, що продукує непорозуміння, екстремізм і девіантні поведінкові відхилення. У нинішньому ефіопському контексті основним джерелом комунікації та неправильної комунікації у соціальних мережах $є$ «плюріверсальні ідентичності» культурного горизонту. У статті обговорюється зв'язок між демократією, федералізмом та соціальними медіа в нинішній Ефіопії. Зокрема висвітлено такі питання: сфера соціальних медіа в Ефіопії, сучасні та постмодерністські виклики соціальних медіа в Ефіопії; альтернативи реконструкції соціальних медіа.

Ключові слова: соціальні медіа, федералізм, демократія, комунікативна раціональність, публічна сфера.

(C) Binyam Mekonnen Adera

Надійшла до редакції: 01.09.2021

Прийнята до друку: 20.09.2021 